\title{
PERANCANGAN E-CUSTOMER RELATIONSHIP MANAGEMENT PADA PT STARSINDO LOGISTICS
}

\author{
Nelly $^{1}$; Hudiarto ${ }^{2}$; Rangga Yudhika ${ }^{3}$ \\ ${ }^{1}$ Jurusan Manajemen, Fakultas Ekonomi, Bina Nusantara University; \\ ${ }^{2}$ Jurusan Sistem Informasi, Fakultas Ilmu Komputer, Bina Nusantara University; \\ ${ }^{3}$ Jurusan Ganda Sistem Informasi - Manajemen, FakultasTeknik, Bina Nusantara University; \\ Jalan K.H. Syahdan No 9, Palmerah, Jakarta Barat 11480 \\ nelly@binus.edu'; hudiarto@binus.edu²; rangga.yudhika@gmail.com³
}

\begin{abstract}
Starsindo Logistics Inc. (SL) is a company in freight forwarding service. The problem in this company is less information provided to customers, especially about customer order status information. It is started from the departure of the EMKL truck until the standard time of customer container entering freight process. Therefore, it is needed to use the customer service application electronic-Customer Relationship Management (e-CRM), because it will ease to manage and control information flow about the customer order status. The research method is following rules in object oriented analysis and design by Mathiassen. Through website, public is hoped to easily access the company information or ship schedule, order list, tracking order status, or transaction history. This web-based customer service application could help the company to build a good relationship with customers.
\end{abstract}

Keywords: electronic-customer relationship management, freight forwarding, tracking, history, object-oriented analysis and design

\begin{abstract}
ABSTRAK
PT Starsindo Logistics (SL) merupakan perusahaan yang bergerak dibidang jasa freight forwarding. Masalah yang dihadapi perusahaan saat ini ialah penyediaan informasi kepada pelanggan yang kurang tepat dan cepat, terutama mengenai informasi status pesanan pelanggan. Permasalahan ini dimulai dari waktu keberangkatan truk EMKL hingga waktu sandar container pelanggan memasuki proses freight. Oleh karena itu dirasa perlu untuk menggunakan aplikasi layanan pelanggan electronic-Customer Relationship Management (eCRM), karena dapat memudahkan untuk mengelola dan mengontrol aliran informasi mengenai status pesanan pelanggan. Metode penelitian yang digunakan adalah mengikuti aturan yang ada pada object oriented analysis and design yang telah diperkenalkan oleh Mathiassen. Melalui website, publik diharapkan dapat dengan mudah mengakses semua informasi mengenai perusahaan maupun jadwal kapal. Pelanggan juga dapat mengakses informasi mengenai jadwal pesanan, tracking status order serta history transaksi yang sudah dilakukan. Dengan adanya aplikasi layanan pelanggan berbasis Website maka diharapkan dapat membantu perusahaan dalam membina hubungan yang lebih baik dengan pelanggan.
\end{abstract}

Kata Kunci: electronic-customer relationship management, freight forwarding, tracking, history, object oriented analysis and design 


\section{PENDAHULUAN}

Berbagai survei menunjukkan bahwa kunci keberhasilan perusahaan bukan semata terletak pada produk ataupun jasa yang ditawarkan namum juga bisa terletak pada seberapa jauh upaya perusahaan dalam memenuhi kebutuhan para pelanggannya. Kepuasan pelanggan dengan sendirinya akan meningkatkan kesetiaan pelanggan pada perusahaan. Kesetiaan pelanggan akan menjadi kunci sukses perusahaan, tidak hanya dalam jangka pendek tetapi akan dapat menjadi keunggulan bersaing yang berkelanjutan.

Perusahaan yang akan maju dalam bisnisnya adalah perusahaan yang senantiasa mendengar dan menindaklanjuti masukan dan keluhan pelanggan. Saat ini merupakan era kedaulatan pelanggan dimana pelanggan tidak hanya menjadi fokus sebuah perusahaan untuk beroperasi dan berproduksi, tetapi juga sebagai aset perusahaan. Persaingan bisnis yang begitu ketat mengharuskan setiap perusahaan memberikan pelayanan yang terbaik kepada pelanggannya.

SL adalah perusahaan yang bergerak dalam bidang pelayanan dan pengiriman barang ekspor serta impor melalui Ekspedisi Muatan Kapal Laut (EMKL), freight (air and sea) serta trucking. Saat ini SL memiliki jumlah pelanggan yang terdiri atas perusahaan-perusahaan besar penghasil produk yang bervariasi. Namun dalam operasional bisnisnya, SL belum dapat memberikan pelayanan berupa aliran informasi yang optimal dengan pelanggannya. Dengan menerapkan sistem CRM, pelayanan kepada pelanggan dapat menjadi lebih baik dan pada akhirnya akan meningkatkan loyalitas pelanggan kepada perusahaan. Kehadiran CRM akan dapat memenuhi dan mengetahui kebutuhan pelanggan secara cepat dan tepat karena CRM mampu mendapatkan inti dari konsep pelanggan dan meletakkannya dalam kerangka aplikasi.

\section{Ruang Lingkup}

Agar lebih terarah, maka ruang lingkup penelitian dibatasi pada perancangan aplikasi e-CRM ditujukan untuk calon pelanggan dan pelanggan dalam memperoleh informasi produk-produk layanan, penyediaan histori dari setiap pelanggan hingga mencakup tracking order. Aliran sumber daya yang ada dalam e-CRM hanya berupa sumber daya informasi, tidak mencakup aliran dokumen karena aliran dokumen tidak dapat dilakukan melalui internet; Penanganan transaksi pada e-CRM ini hanya mencakup pelayanan EMKL dan Sea Freight karena transaksi ini memegang porsi pelayanan terbesar yang dilakukan oleh pelanggan dibandingkan pelayanan lain.

\section{Tujuan dan Manfaat}

Tujuan dari penulisan ini adalah agar perusahaan memiliki sistem e-CRM melalui tersedianya Website perusahaan; membantu perusahaan dalam memberikan pelayanan informasi yang lebih baik; dengan tersedianya Website yang dapat diakses kapan saja dan dimana saja, pelanggan dapat mengakses informasi, memberikan saran, kritik dan tanggapan maupun pertanyaan kepada perusahaan.

Manfaat yang diharapkan adalah dapat membantu perusahaan dalam menyampaikan informasi profil perusahaan, jasa beserta rute pelayanan yang dilayani kepada pelanggan; membantu perusahaan dalam menyediakan informasi kepada pelanggan mengenai pelayanan-pelayanan yang pernah digunakan pelanggan; membantu membina hubungan yang baik dengan pelanggan untuk jangka panjang melalui fasilitas contact center. 


\section{Kajian Teori}

\section{Customer Relationship Management (CRM)}

Konsep dari relationship marketing dasar pertama kali dikemukakan pada tahun 1983. Dari konsep hubungan pemasaran itulah terbangun CRM. Yang menjadi perbedaan utama hanyalah hubungan pemasaran yang kurang atau tidak menggunakan teknologi informasi. Sedangkan pada pengembangan CRM saat ini, seharusnya dilakukan dengan memperhatikan aspek teknologi, yaitu sistem dan bahkan melalui Website. Mengutip definisi CRM menurut Kalakota (2000), CRM berarti dilakukannya segmentasi pelanggan dan menawarkan kepada mereka nilai berupa harga, kualitas, fitur produk, merek, pelayanan dan pengalaman sangat menyenangkan. CRM didefinisikan sebagai integrasi antara penjualan, pemasaran dan strategi pelayanan.

\section{Berbagai Jenis CRM}

Menurut Greenberg (2005), CRM berdasar segmennya terbagi atas operational, analytical, dan collaborative.

\section{Operational CRM}

Operational CRM mencakup kepada transaksi dalam melayani pelanggan dari internal perusahaan. Fungsi bisnis umum mencakup pelayanan, manajemen pemesanan, tagihan, penjualan otomatisasi penjualan dan pemasaran. Bagian dari operational CRM mencakup kepada pusat kontak pelanggan, atau biasa disebut Customer Interaction Center (CIC).

\section{Analytical CRM}

Analytical CRM mencakup penangkapan, penyimpanan, penjabaran, pemrosesan, pelaporan data pelanggan kepada pengguna, bukan hanya algoritma dan penyimpanan, tetapi juga respon terhadap personalisasi penggunaan data.

\section{Collaborative CRM}

Merupakan pusat komunikasi, jaringan koordinasi yang merujuk kepada lajur pelanggan dan supliernya sendiri. Dimaksudkan seperti web atau e-mail. Jenis ini biasa disebut juga sebagai strategi hubungan, fungsi CRM yang menyediakan interaksi antara pelanggan dan jalur mereka sendiri.

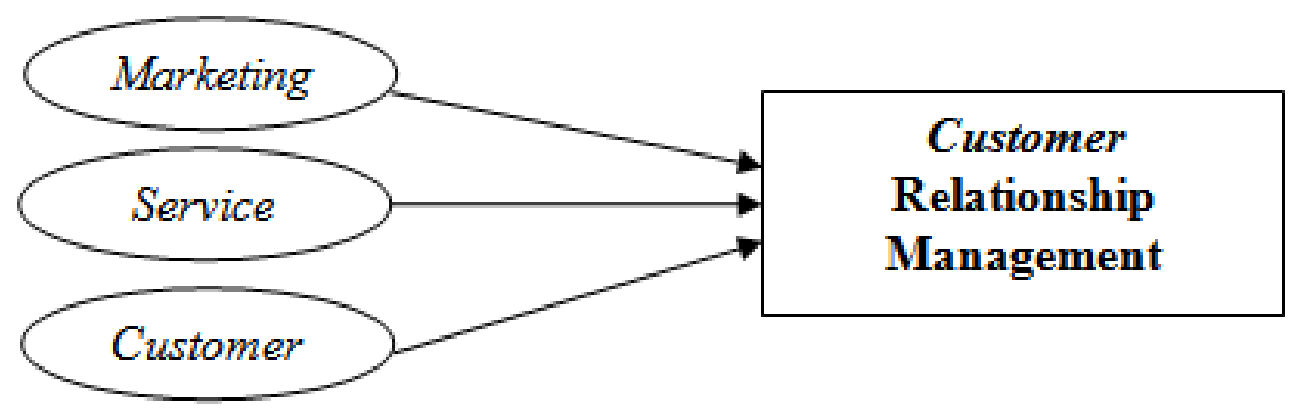

Gambar 1 Integrasi CRM

Sumber: Kalakota (2000) 


\section{E-CRM}

Dengan menggabungkan unsur teknologi informasi dan internet, maka konsep CRM akan dinamakan e-CRM di mana secara konsep CRM yang ada, yaitu pengaturan aktivitas hubungan dengan pelanggan dibangun diatas basis Website elektronik. Mengutip dari Kalakota \& Robinson (2000), e-CRM merupakan manajemen pelanggan untuk e-Bisnis yang harus berhadapan dengan kompleksitas dari manajemen yang menarik pelanggan dan partner bisnis dalam berbagai macam media yang meliputi media online dan offline, personal contact dan media komunikasi elektronik lainnya.

\section{Analisa Critical Success Factor (CSF)}

Analisa CSF merupakan faktor-faktor yang harus benar sehubungan dengan pengorganisasian dalam mencapai tujuan. Faktor-faktor tersebut dapat berada di level divisi maupun manajerial. Sekali CSF diidentifikasikan, selanjutnya dapat dipantau, diukur dan dibandingkan dengan standar-standar.

\section{Metode Analisis dan Perancangan Sistem Berorientasi Objek}

Object Oriented Analysis and Design berusaha untuk menggabungkan data dan proses menjadi suatu gagasan tunggal yang disebut object (objek). Object Oriented Analysis and Design memperkenalkan object diagram yang mendokumentasikan sistem dipandang dari segi object dan interaksinya. Terdapat 4 aktivitas utama dalam Object Oriented Analysis and Design, yaitu Problem Domain Analysis, Application Domain Analysis, Architectural Design, dan Component Design.

Problem domain dapat didefinisikan sebagai bagian dari sebuah keadaan yang dikelola, diawasi atau dikontrol oleh sistem (Mathiassen et al, 2000). Menurut Mathiassen et al (2000), "tujuan dari problem domain analysis adalah untuk mengembangkan model yang dapat digunakan untuk merancang dan mengimplementasikan sebuah sistem yang dapat memproses, mengkomunikasikan, dan memberikan informasi mengenai problem domain dalam cara yang tepat dan dapat digunakan”.

Application domain adalah organisasi yang mengelola, mengawasi, atau mengontrol sebuah problem domain. Hal pertama yang dilakukan dalam analisis ini adalah mendefinisikan kebutuhan fungsi dan tampilan sistem. Fokus analisis ditempatkan pada pekerjaan user untuk menjabarkan kebutuhan secara rinci. Dari hasil kebutuhan tersebut, dapat dibentuk konsep yang dimodelkan sebagai classes, events, dan structures yang akan dijelaskan labih lanjut pada problem domain analysis. Perbedaan dari sistem yang sukses dengan system yang kurang sukses terletak pada architectural design yang baik. Architecture (arsitektur) dari sebuah sistem memenuhi perancangan kriteria tertentu, juga berguna sebagai kerangka kerja untuk aktivitas pengembangan yang tersisa. Sedangkan tujuan dari component design adalah untuk menentukan sebuah implementasi dari persyaratan kebutuhan dalam architectural framework (Mathiassen et al, 2000).

\section{Permasalahan yang dihadapi}

SL memiliki beberapa masalah dalam melakukan pelayanan kepada pelanggan, yang diantaranya: penelusuran status pesanan pelanggan yang sering kali menjadi masalah harian, belum tersedianya media informasi dalam melakukan pencatatan histori serta media sebagai interaksi antara pelanggan dan perusahaan. Dari wawancara dan kuesioner dengan manajer dan juga karyawan pada divisi sales and marketing serta divisi customer service, permasalahan diatas menjadi permasalahan fundamental yang terjadi sehari-hari. 


\section{PEMBAHASAN}

\section{Visi dan Misi Perusahaan}

Sesuai dengan visi dari SL adalah menjadi partner utama sebagai perusahaan freight forwarding specialist yang memiliki komitmen, konsistensi serta terpercaya dalam cakupan domestik. Visi tersebut dirumuskan di dalam misi PT. Starsindo yaitu memenuhi kebutuhan logistik global yang luas dengan diiringi pelayanan yang optimum, mengembangkan sumber daya manusia sebagai aset penting dalam setiap proses kerja, dan memiliki hubungan sinergi yang erat dengan klien, agen dan carrier.

Perumusan misi tersebut akan diselaraskan dengan strategi perusahaan yang diikuti dengan penentuan CSF (Critical Success Factor). CSF yang menjadi point kritis yang akan menentukan keberhasilan strategi adalah penetrasi pasar, pengembangan pasar, dan integrasi ke belakang.

\section{Penetrasi Pasar}

CSF: Memberikan layanan atas penyaluran informasi; pelayanan yang bisa diberikan tidak hanya selama pengajuan permintaan pelayanan (pre-ordering) dan pemenuhan pesanan (orderprocessing) saja, melainkan juga hingga setelah berakhirnya pelayanan (post-ordering). Penetrasi pasar dapat dilakukan dengan mempromosikan jenis pelayanan (melalui web) dan rute yang ada dengan gencar dan juga dapat dilakukan dengan meningkatkan pelayanan terhadap pelanggan.

\section{Pengembangan Pasar}

CSF: Mengenalkan Eksistensi Perusahaan; pengembangan pasar merupakan tindakan dalam memasuki pasar yang baru yang belum pernah dimasuki sebelumnya. Untuk memasuki pasar tersebut pertama-tama harus melakukan branding perusahaan dan salah satu metodenya adalah dengan memanfaatkan web e-CRM. Web tersebut juga dapat digunakan untuk menyalurkan informasi kepada pelanggan yang tersebar di wilayah-wilayah lain diluar jangkauan Branch dan sub Branch perusahaan.

\section{Integrasi ke Belakang}

CSF: Meningkatkan jumlah Koneksi (relasi bisnis) dengan perusahaan pengguna jasa dan pemilik rental truk; strategi integrasi ke belakang dapat dilakukan oleh perusahaan dalam memperoleh pilihan-pilihan terbaik yang lebih banyak untuk menggunakan jasa perusahaan Shipping maupun rental truk. Dengan memiliki pilihan-pilihan yang lebih banyak, maka perusahaan dapat meminimalkan ancaman akan ketergantungan pada pihak-pihak tertentu.

\section{Usulan Pemecahan Masalah}

Setelah mengidentifikasikan permasalahan-permasalahan yang didapat dari analisis sistem berjalan dan analisis industri melalui matriks QSPM didapat bahwa strategi perusahaan yang paling cocok adalah pengembangan produk pelayanan dan pengembangan pasar. Seiring dengan strategi tersebut, kelengkapan dan kemudahan akan akses terhadap informasi menjadi kebutuhan yang harus dikembangkan melalui pemanfaatan website e-CRM yang menyediakan fasilitas: (1) dapat menyediakan informasi yang up-to-date dan dapat diakses, oleh pelanggan secara real-time Penyediaan Informasi berupa schedule, rute pelayanan, history transaksi berikut status pelayanan dan administrasi menjadi kebutuhan-kebutuhan atas informasi pada diri pelanggan; (2) memperkenalkan PT. Starsindo melalui media web dan pelayanannya. Dengan sering timbulnya pertanyaan pelanggan kepada Customer Service mengenai waktu keberangkatan truk dari depo dan waktu pengangkutan 
barang pelanggan ke shipping line, maka permasalahan tersebut akan dapat teratasi dengan adanya tracking access; (3) melalui web ini juga disediakan sarana contact center yang mampu menampung aspirasi, keluhan dan komentar pelanggan terhadap perusahaan.

\section{Sistem E-CRM yang Diusulkan}

Berdasarkan hasil analisis terhadap sistem pelayanan pada PT. Starsindo Logistics, maka penulis mengusulkan adanya sistem pelayanan pelanggan berbasis Web melalui sistem E-CRM. Dengan adanya situs Web ini, diharapkan perusahaan dapat memberikan pelayanan yang lebih maksimal melalui fungsi-fungsi yang ada. Sistem ini diperuntukkan kepada publik pada umumnya dan kepada pelanggan pada khususnya. Tiga fase CRM yang terdapat dalam sistem e-CRM yang diusulkan yaitu fase acquire, fase enhance, dan fase retain.

\section{Fase Acquire (Mendapatkan pelanggan)}

Fase mendapatkan pelanggan ini tampak dalam penyediaan informasi mengenai profil, visi dan misi perusahaan, serta promosi produk pelayanan apa saja yang ditawarkan kepada pelanggan berikut rute-rute tujuan. Dengan memberikan informasi-informasi tersebut, perusahaan dapat turut melaksanakan strategi penetrasi pasar dan pengembangan pasar.

\section{Fase Enhance (Meningkatkan hubungan)}

Melalui web yang akan dikembangkan, dapat dilakukan juga tahap peningkatan hubungan yang tidak hanya sekedar manual (phone-by-phone). Hubungan yang ada dapat terjalin dengan lebih baik melalui fungsi-fungsi seperti sarana contact center yang menggantikan peran Customer service untuk menjawab dan memenuhi kebutuhan pelanggan dan merespon balik atas kuesioner yang telah diisi oleh pelanggan yang bersangkutan untuk mengetahui dan memenuhi kebutuhan pelanggan.

\section{Fase Retain (Mengikat pelanggan)}

Tahap ini mengikat pelanggan yang sudah ada dan menjalin hubungan yang lebih baik sehingga mampu meningkatkan loyalitas pelanggan yaitu melalui fungsi memberikan informasi mengenai tracking access akan keberadaan truk yang menuju gudang pelanggan dan pelabuhan, menu order history memungkinkan pelanggan untuk dapat melihat transaksi yang telah dilakukannya, menu quotation request menungkinkan pelanggan untuk dapat meminta pelayanan khusus seperti project service, melakukan interaksi secara personal melalui menu message.

\section{Problem Domain}

Hasil analisis pada problem domain salah satunya dinampakkan pada class diagram seperti yang tertera pada gambar 2 di bawah ini.

\section{Application Domain}

Hasil rancangan utama salah satunya adalah struktur Web dan sebagai contoh dipaparkan struktur Web Publik dan struktur Web Customer serta struktur Web Admin. 


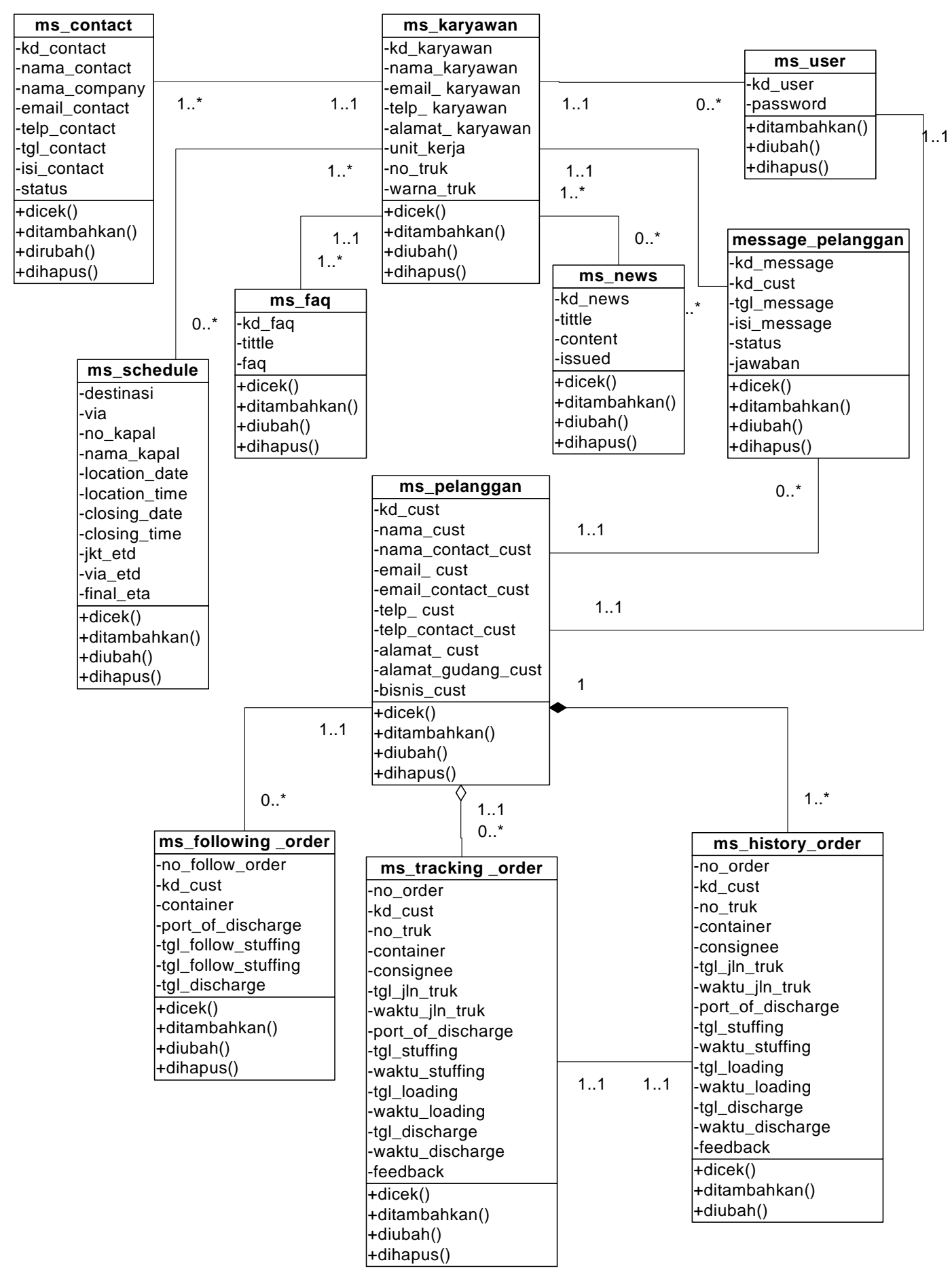

Gambar 2 Class Diagram 


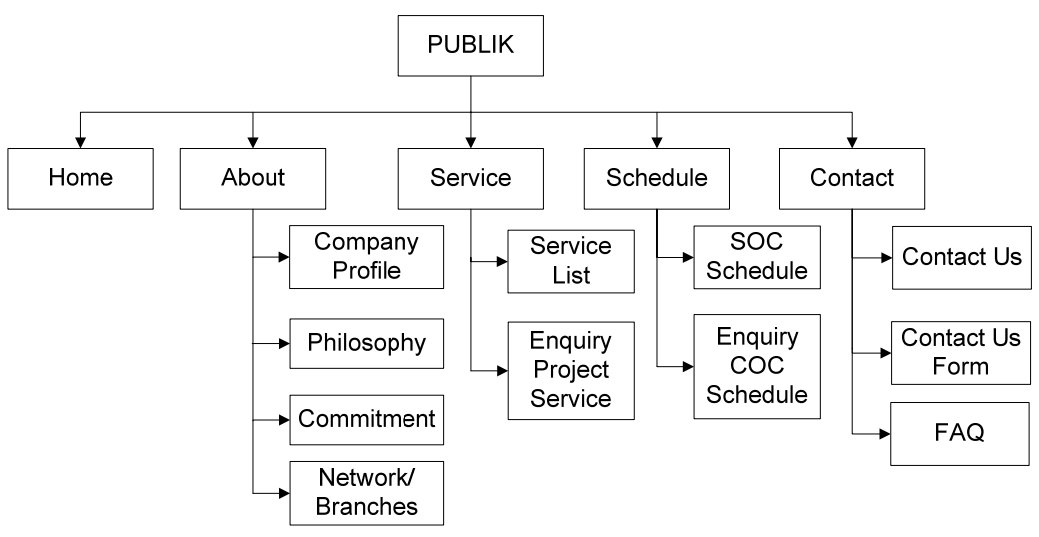

Gambar 3 Struktur Web Publik

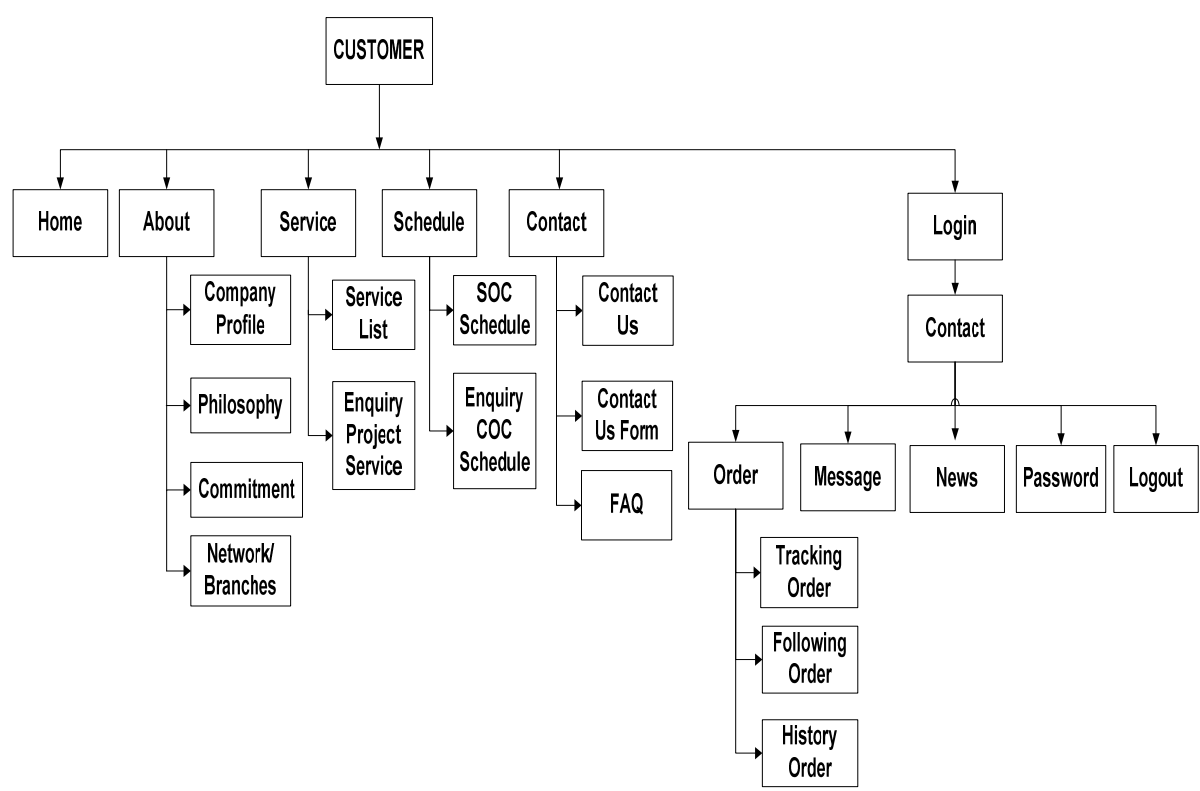

Gambar 4 Struktur Web Customer

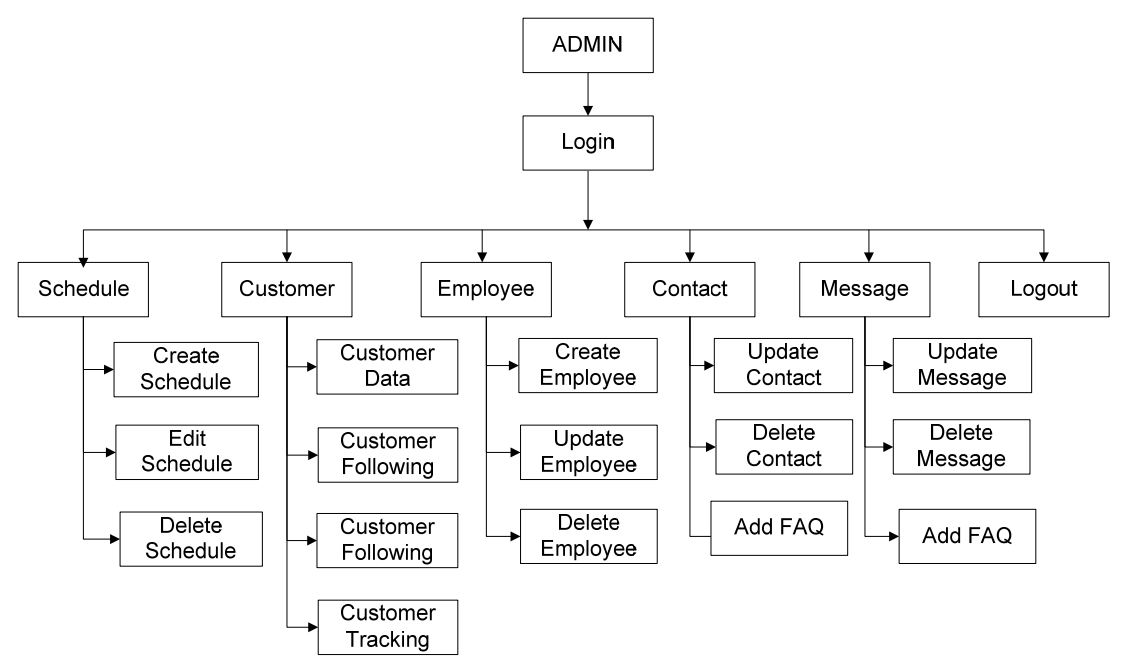

Gambar 5 Struktur Web Admin 


\section{Use Case Web Publik}

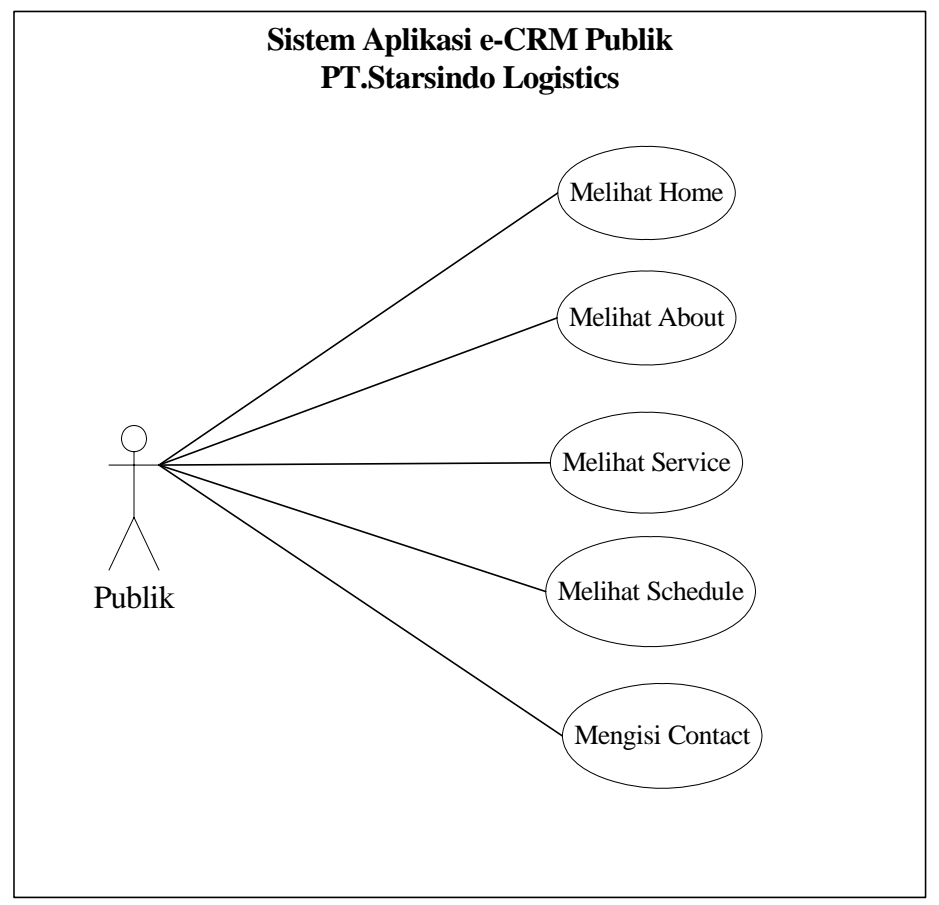

Gambar 6. Use Case Web Publik

\section{Use Case Web Pelanggan}

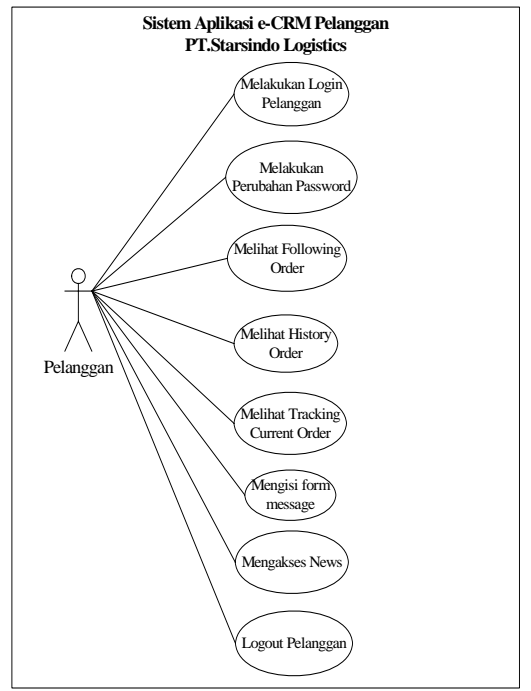

Gambar 7 Use Case Web Pelanggan

\section{Component Design - Component Architecture}

Component Architecture merupakan struktur sistem yang terdiri dari komponen yang memiliki interkoneksi. Component Architecture menggambarkan arsitektur sistem yang telah dipilih. Rancangan sistem akan memiliki komponen dasar seperti User Interface (UI), komponen fungsi 
(function), komponen model (model) dan juga System Interface (SI). Sistem akan dijalankan di jaringan Internet dengan arsitektur client-server yang memiliki konsep centralized data. Client yang ada pada sistem ini dirancang untuk client pelanggan (termasuk publik) dan client admin.

Client memiliki pola User Interface, Function dan System Interface. User Interface (UI) merupakan tampilan yang menghubungkan pengguna (User) dan juga sistem. User Interface diantara pelanggan dan admin berbeda, oleh karenanya function (F) yang dimiliki pun berbeda. Function merupakan suatu kegiatan yang melakukan suatu fungsi seperti fungsi penambahan data Order dan juga fungsi pengiriman pesan oleh pelanggan. Sedangkan system interface (SI) merupakan suatu komponen dimana menghubungkan sistem yang ada di computer client dengan server.

Server yang ada merupakan sebuah computer server yang memiliki komponen function dan juga model. Komponen function terdapat di dalam server karena terdapat fungsi-fungsi yang tidak terdapat pada fungsi admin maupun pelanggan. Fungsi-fungsi tersebut diantaranya adalah fungsi validasi login, fungsi perubahan data. Komponen model (M) yang ada di dalam server lebih menyerupai database yang disimpan di sisi

server.

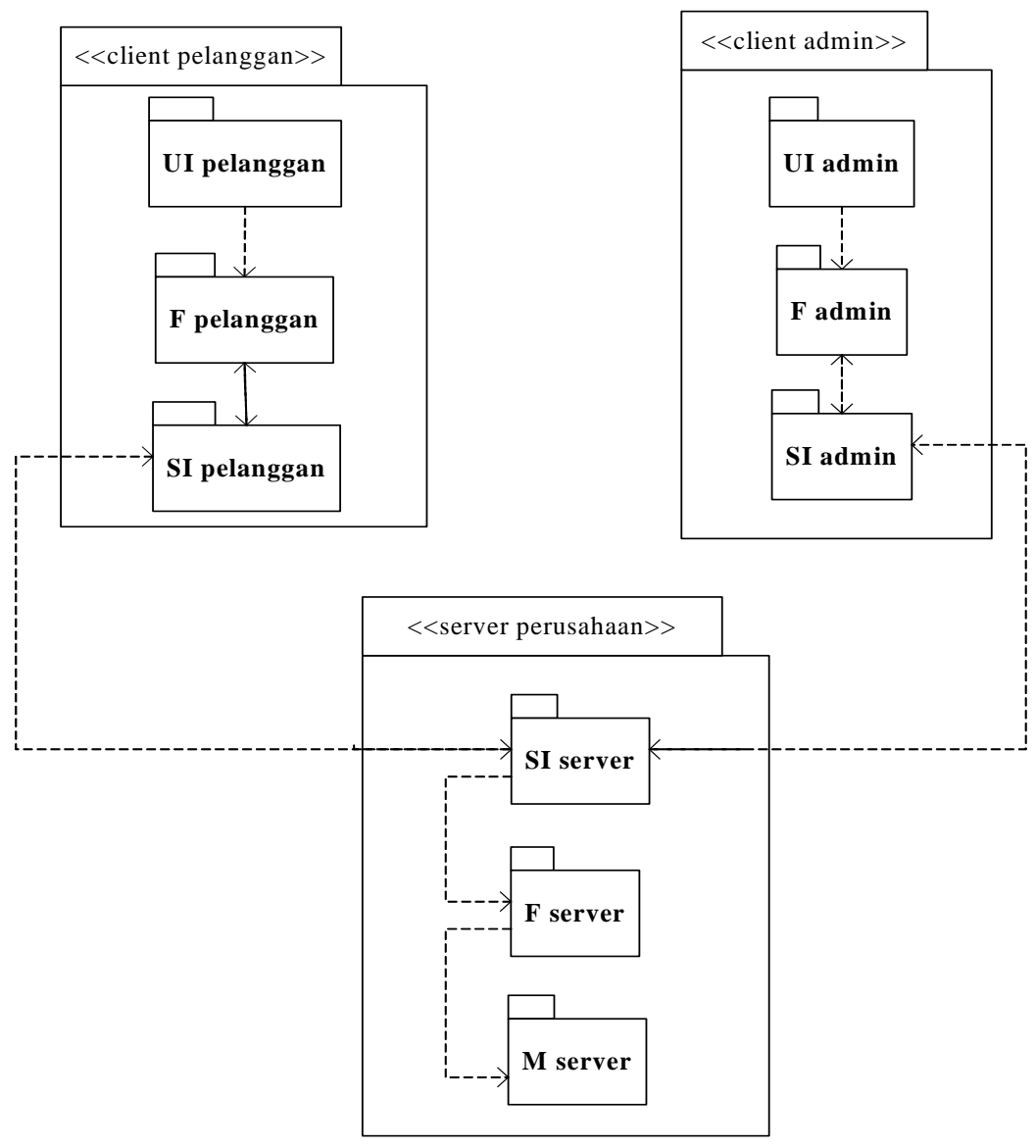

Gambar 8. Component Architecture

Process Architecture merupakan struktur eksekusi sistem yang terdiri dari proses yang saling interdependent (bergantungan). Process Architecture ini lebih menekankan kepada proses yang ada diantara client dan server, serta proses yang dijalankan dalam arsitektur system yang telah dipilih. Client yang ada yaitu pelanggan (meliputi publik) dan juga admin serta server terdiri atas server perusahaan. Pola di dalam proses ini merupakan centralized data. 
Komponen yang ada pada server yaitu komponen model yang mengirimkan kebutuhan kepada system interface yang ada di sisi client. System interface (UI) akan mengirimkan tampilan yang dibutuhkan pada Function (F). Selanjutnya melalui User interface itulah client bisa melakukan fungsifungsi di dalam sistem. Karena keseluruhan model untuk masing-masing client sama maka model (M) dapat diletakkan di server.

Proses arsitektur dapat dilihat pada gambar berikut ini:

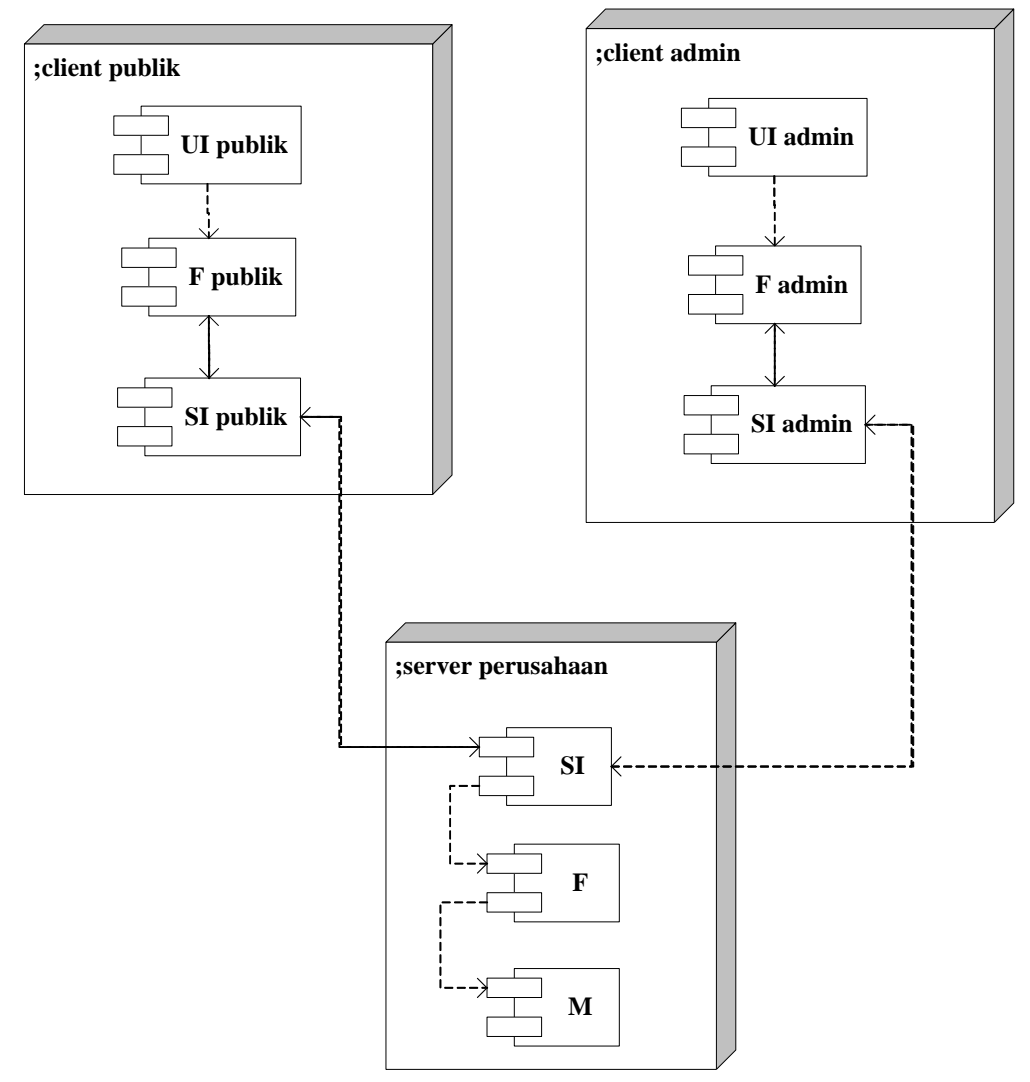

Gambar 9 Proses Arsitektur

\section{PENUTUP}

Adapun simpulan yang dapat diambil sebagai berikut: Dilihat dari sistem yang berjalan, permasalahan yang sering timbul mengenai informasi status pesanan dan belum tersedianya media yang dapat menjadi fasilitator dalam penyediaan informasi kepada pelanggan menjadi dasar pembuatan Website berbasis Customer Relationship Management; Strategi yang dapat menjadi prioritas untuk diterapkan oleh perusahaan sesuai dengan hasil analisis adalah strategi penetrasi pasar, pengembangan pasar dan integrasi ke belakang. Website yang ada dirancang untuk publik pada umumnya maupun pelanggan pada khususnya dan dapat dimanfaatkan sebagai layanan promosi, penyediaan informasi dan komunikasi antara perusahaan dengan pelanggan. Selain itu sistem ini dapat menjadi media dalam menyediakan informasi kepada pelangan mengenai tracking order, history transaksi dan juga following order pelanggan. Dan pada akhirnya sistem e-CRM yang dirancang harus dapat mendukung CRM yang sudah ada saat ini. Dengan menerapkan sistem e-CRM ini perusahaan diharapkan dapat meningkatkan kepuasan pelanggan melalui penyediaan informasi yang akurat dan cepat. 
Selanjutnya saran-saran yang dapat disampaikan adalah sebagai berikut: dengan diimplementasinya sistem ini, perusahaan seharusnya berkomitmen terhadap pemeliharaan Website. Perusahaan perlu melakukan pelatihan SDM dalam mengoperasikan Website, yaitu Admin dan juga Customer Service. Kemudian, perusahaan diharapkan menaruh perhatian terhadap spesifikasi hardware dan software yang dibutuhkan terhadap perubahan di masa mendatang. Memperluas cakupan pelayanan di dalam sistem yang lebih luas selain pelayanan terhadap jasa EMKL dan Freight dan beberapa aplikasi, infrastruktur, service dan manajemen hubungan pelanggan perlu dioptimalkan sehingga dapat terus meningkatkan hubungan pelanggan yang lebih baik terutama melalui peningkatan kepuasan.

\section{DAFTAR PUSTAKA}

Greenbeerg, P. (2005). CRM at the speed of light (3rd ed.). New York, USA: McGraw-Hill.

Kalakota, R., \& Robinson, M. (2000). E-Business: Roadmap for success. New York: Addison-Wesley. 